\title{
Analisis Decision Support System Perbandingan Metode Smarter dan Saw Dalam Menentukan Pemilihan Staff Pegawai Terbaik Laboratorium Komputer
}

\author{
Nandri Marsan Sitinjak ${ }^{1}$, Muhammad Zarlis ${ }^{2}$, Roslina $^{3}$ \\ ${ }^{1}$ Fakultas Teknik dan Ilmu komputer, Prodi Magister Ilmu Komputer, Universitas Potensi Utama, Medan, Indonesia \\ 2 Universitas Sumatera Utara, Medan, Indonesia \\ 3 Politeknik Negeri Medan, Medan, Indonesia \\ Email: 1," naandrimarsan@gmail.com, ${ }^{2}$ muhammadzarlis@gmail.com, ${ }^{3}$ roslinanich@gmail.com \\ Email Penulis Korespondensi: naandrimarsan@gmail.com
}

\begin{abstract}
Abstrak-Staff pegawai terbaik akan membuat suatu pihak instansi menjadi meningkat dalam operasionalnya dan dapat berkembang secara pesat. Namun kendala pada pihak suatu instansi, sangat masih belum optimal dalam pelaksanaan pemilihan staff pergawai terbaik. Oleh karena itu diperlukan manajemen sumber daya manusia disuatu instansi dengan pemilihan staff pegawai terbaik untuk memacu semangat kerja staff pegawai dalam meningkatkan opersional, dedikasi dan kinerjanya pada suatu instansi tersebut, sehingga menjadi lebih baik yaitu dengan dengan membuat suatu Decision Support System dalam pemilihan staff pegawai terbaik dengan menggunakan metode perbandingan metode Smarter dan Saw. Metode Smarter dan Saw adalah metode pengambilan keputusan menggunakan perkalian untuk menghubungkan nilai kriteria, yang dimana nilai untuk setiap kriteria harus dihitung terlebih dahulu dengan bobot setiap kriteria yang bersangkutan. Dengan memanfaatkan kelebihan dan kekurangan masing-masing metode perbandiingan ini mampu menghasilkan akurasi senilai 79,5 untuk metode Smarter, 93 untuk akurasi menggunakan SAW. Sistem pendukung keputusan dengan menggunakan metode perbandingan ini dapat membantu mempermuah proses pemilihan pegawai terbaik dan memberikan alternatif pilihan hasil perangkingan.
\end{abstract}

Kata Kunci: Decision Support System, Staff Pegawai, Smarter, Saw.

Abstract-The best employees will make an agency to increase in its operations and can develop rapidly. However, relations on the part of an agency are still not optimal in selecting the best staff. Therefore, human resource management is needed in an agency with the selection of the best employee staff to spur staff morale in improving operations, dedication and performance in an agency, so that it becomes better, namely by creating a Decision Support System in selecting the best staff employees by using the Smarter and Saw method comparison method. The Smarter and Saw method is a decision-making method using multiplication to determine the value of a criterion, where the value for each criterion must be determined in advance with the weight of each criterion concerned. By utilizing the advantages and disadvantages of each method, the comparison of this method is able to give a value of 79.5 for the Smarter method, 93 for using SAW. Decision support systems using this comparison method can assist in the selection of the best employees and provide an alternative choice of ranking results.

Keywords: Decision Support System; Staff; Smarter; SAW

\section{PENDAHULUAN}

Staff pegawai yang berkualitas merupakan salah satu faktor pendukung yang sangat penting dalam perkembangan suatu pihak instansi. Dengan adanya staff pegawai yang berkualitas akan membuat suatu pihak instansi menjadi meningkat dalam operasionalnya, berkembang secara cepat dan menjadi terkenal. Oleh karena itu diperlukan manajemen sumber daya manusia disuatu pihak instansi dengan pemilihan staff pegawai yang terbaik untuk memacu semangat kerja staff pegawai dalam meningkatkan operasionalnya, dedikasi dan kinerjanya disuatu instansi tersebut sehingga menjadi lebih maju dan berkembang [1]

Namun kendala pada pihak suatu instansi, masih belum optimal yaitu masih dengan sistem manual dalam penilaian staff pegawai terbaik dahulunya, sehingga saat ini sudah tidak ada yang memproses pemilihan staff pegawai laboratorium terbaik, karena tidak efektif dan efisien dalam pelaksanaa pelaksanaan pemilihan staff pegawai terbaik, dan tanggung jawab dalam pekerjaan staff pegawai tersebut belum maksimal, sehingga tidak terstruktur, hal ini disebabkan karena saat ini belum tersedianya lagi media yang memproses penilaian staff pegawai terbaik yang efektif dan efisien [2]

Beberapa penelitian terdahulu yang sudah dilakukan menggunakan metode Smarter dan SAW antara lain : 1. "Sistem Pendukung Keputusan Pemilihan Pegawai Terbaik PT Pegadaian Jakarta Dengan Metode Simple Additive Weighting". Dalam proses penentuan ranking pegawai yang dilakukan melalui perhitungan dengan metode Simple Additive Weighting (SAW) dimulai dengan pemberian nilai kriteria, pembobotan, rating kecocokan, normalisasi, dan perankingan. Sehingga menghasilkan nilai dari masing - masing kriteria. Berdasarkan hasil analisis perhitungan dengan nilai tertinggi dengan menggunakan metode Simple Additive Weighting untuk menentukan pegawai terbaik dipilih pegawai dengan NIP P.86106681 sebagai pegawai terbaik. Untuk peneltian selanjutnya dibutuhkan suatu aplikasi sehingga proses pengambilan keputusan menjadi lebih cepat dan efisien [3]

2. "Perancangan Sistem Pendukung Keputusan Pemilihan Pegawai Teladan Menggunakan Metode SAW (SIMPLE ADDITIVE WEIGHTING) Berbasis Web Di Dinas Penanaman Modal DAN Pelayanan Terpadu Satu Pintu Kabupaten Kebumen". Pemilihan Pegawai Teladan yang masih berjalan secara menual dan belum adanya metode yang dijadikan dasar dalam perhitungan nilai - nilai yang didapat oleh pegawai. Perhitungan 
nilai yang masih manual dan membutuhkan waktu yang lama dalam proses perhitungan mengakibatkan ketidak efisiennan waktu [4]

3. "Implementasi Metode Simple Multy Attribute Rating Technique Exploiting Ranks (Smarter) Dan Forward Chaining Pada Penentuan Posisi Karyawan Baru PT. Langgeng Buana Jaya, Gresik". Penentuan posisi karyawan baru di PT Langgeng Buana Jaya dengan menggunakan metode manual menyebabkan ketidak sesuaian skill dan lingkungan kerja karyawan. Hal itu dibuktikan dengan penelitian dari 10 sample karyawan baru hanya 4 posisi yang sesuai dengan kemampuan karyawan dan terdapat 2 karyawan yang tidak layak tapi dapat diterima, kombinasi metode SMARTER dan Forward Chaining dapat menjadi solusi penentuan posisi karyawan sekaligus menilai kelayakan karyawan. Kekurangan dari penelitian ini adalah perlu diterapkan dengan data yang lebih besar dan kategori yang lebih banyak dan variatif untuk menguji kombinasi kedua metode ini [5]

4. "Sistem Pendukung Keputusan Pemilihan Dosen Berprestasi Menggunakan Metode SMARTER Pada Universitas Budi Darma”. Sistem pendukung keputusan merupakan sebuah sistem yang tepat digunakan untuk melakukan pemilihan dosen berprestasi pada Universitas Budi Darma. Dengan menggunakan sebuah sistem pendukung keputusan kiranya mendapatkan tolak ukur yang valid bagi Pimpinan Universitas Budi Darma. Pada penelitian ini dilakukan pemilihan dosen berprestasi dengan menggunakan metode SMARTER yang dimana pada SMARTER pembobotan pada kriteria dan subkriteria dilakukan dengan menggunakan metode ROC [6]

Berdasarkan masalah tersebut, hal ini melahirkan suatu decision support system salah satu seleksi yang dapat digunakan untuk pemilihan staff pegawai terbaik. Decision Support System dapat digambarkan sebagai sistem yang berkemampuan untuk mendukung analisi data, dan pemodelan keputusan, berorientasi keputusan dan orientasi perencanaan masa depan. Metode yang digunakan adalah metode perbandingan SMARTER dan SAW dalam menentukan staff pegawai terbaik, perhitungan kedua metode tersbut akan dibandingkan mana metode yang lebih efektif dan efisien.

\section{METODOLOGI PENELITIAN}

Dalam melakukan penelitian ini, pengumpulan data dan informasi pada tahap ini dilakukan untuk mengetahui mengenai sistem yang diteliti. Metode yang digunakan penulis untuk pengumpulan data adalah sebagai berikut :

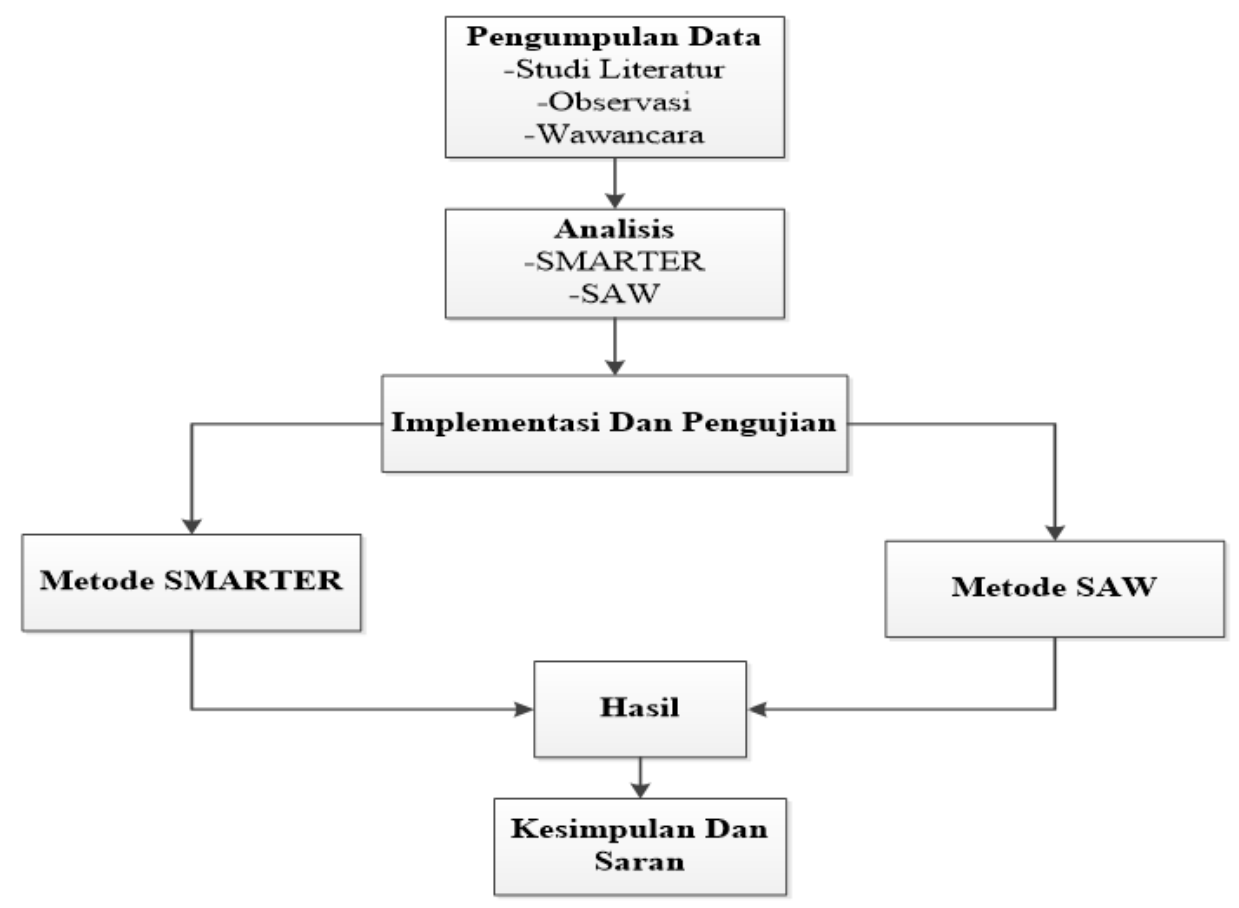

Gambar 1. Tahapan Metodologi Penelitian

Penulis melakukan pengumpulan data-data yang berkaitan dengan penelitian penulis. Pengumpulan data yang dilakukan diantaranya :

1. Studi literatur

Penulisan ini dimulai dengan studi kepustakaan, yaitu dengan mengumpulkan bahan-bahan referensi dari jurnal untuk pembuatan aplikasinya.

2. Observasi 
Pada bagian ini dilakukan proses pengamatan terhadap penentuan dosen terbaik. Hal-hal yang termasuk kedalam kegiatan observasi ini antara lain adalah mengambil kriteria yang dibutuhkan dalam penelitian serta melakukan analisa dalam melakukan penentuan dosen terbaik, berdasarkan pilihan kebutuhan manajemen untuk mendukung tercapainya tujuan penelitian.

\subsection{Decision Support System (Sistem Pendukung Keputusan)}

Decision Support System merupakan serangkaian prosedur yang saling berhubungan dalam melaksanakan suatu pekerjaan tertentu. Sistem ini beridiri dari unsur yang dapat dikenal, saling melengkapi, tujuan, dan sasaran. Suatu sistem dapat terdiri dari beberapa subsistem dan subsistem dapat pula terdiri dari beberapa subsistem [7].

\subsection{Karyawan}

Karyawan merupakan salah satu sumber daya yang digunakan sebagai alat penggerak dalam memajukan suatu perusahaan. Kinerja karyawan cukup berpengaruh dalam keuntungan yang didapat oleh perusahaan tersbut. Untuk memacu kinerja karyawan, maka suatu perusahaan melakukan pemilihan karyawan terbaik setiap periodenya dengan memberikan bonus ataupun kenaikan gaji pada setiap karyawan yang terpilih [8] .

\subsection{Metode SAW}

Metode Simple Additive Weighting (SAW) sering juga dikenal istilah metode penjumlahan terbobot. Konsep dasar metode SAW adalah mencari penjumlahan terbobot dari rating kinerja pada setiap alternatif pada semua atribut. Metode SAW membutuhkan proses normalisasi keputusan kesan (x) kesuatu skala yang dapat diperbandingkan dengan semua rating alternatif yang ada [9].

\subsection{Metode Smarter}

Metode Smarter (Simple Multi-Atrribute Rating Technique Exploiting Ranks) merupakan modifikasi dari metode SMART (Simple Multi Atrribute Rating Technique), dimana kedua metode ini digunakan untuk menentukan bobot dari setiap kriteria dalam suatu pengambilan keputusan. Bobot setiap kriteria menentukan tingkat kepentingan dari kriteria tersebut. Rumus Metode SMARTER secara umum [10]. Bobot W didapat dari:

$$
\begin{aligned}
& \sum^{R}-{ }_{1} W_{1} U_{(1)} \forall=1 \ldots . . n \\
& W_{k}=(1 / k) \sum_{1}^{k}-k(1 / 1) \ldots .
\end{aligned}
$$

\section{HASIL DAN PEMBAHASAN}

\subsection{Analisa Pemilihan Karyawan Terbaik}

Sebagai langkah awal yang dilakukan dalam studi kasus tersebut adalah untuk mengetahui gambaran permasalahan dalam pemilihan staff pegawai terbaik dengan melakukan analisa perbandingan dua metode permasalahan yang dapat memberikan solusi sesuai dengan permasalahan yang ada.

\subsection{Penerapan Metode SMARTER}

Berikut akan dijelaskan contoh kasus sederhana dengan penyelesaian menggunakan metode SMARTER untuk pemilihan pegawai staff laboratorium.

1. Merumuskan masalah yaitu pemilihan staff pegawai laboratorium

2. Menentukan kriteria yang digunakan dalam pemilihan staff pegawai laboratorium.

3. Menentukan alternatif personel yang layak untuk masuk ke tahap perhitungan (i). Contoh sampel 5 orang.

4. Menentukan peringkat untuk masing-masing kriteria.

Kriteria yang dibutuhkan adalah kriteria-kriteria yang baik sesuai dengan standar. Dibawah ini merupakan tabel kriteria yang akan diteliti untuk menentukan pemilihan staff pegawai laboratorium, yaitu:

Tabel 1. Peringkat Setiap Kriteria

\begin{tabular}{cc}
\hline No & Kriteria \\
\hline 1 & Keahlian \\
2 & Disiplin \\
3 & Kepribadian \\
4 & Kerja Team \\
5 & Komunikasi \\
6 & Penampilan \\
7 & Sikap \\
\hline
\end{tabular}

5. Memberikan bobot berdasarkan kriteria paling penting dan kriteria paling tidak penting. Kriteria paling penting disetkan dengan bobot 100 dan kriteria paling tidak aman disetkan dengan nilai 10 [11]. 


\section{JURNAL MEDIA INFORMATIKA BUDIDARMA}

Volume 5, Nomor 2, April 2021, Page 495-503

ISSN 2614-5278 (media cetak), ISSN 2548-8368 (media online)

Available Online at https://ejurnal.stmik-budidarma.ac.id/index.php/mib DOI 10.30865/mib.v5i2.2926

6. Memberikan bobot kepada setiap alternatif berdasarkan setiap kriteria. Bobot alternatif dalam skala 0-100. Nol sebagai nilai minimum dan 100 sebagai nilai maksimum.

Tabel 2. Data rating kecocokan alternatif terhadap setiap kriteria

\begin{tabular}{ccccccccc}
\hline No & Nama & Keahlian & Kedisiplinan & Kepribadian & $\begin{array}{c}\text { Kerja } \\
\text { Team }\end{array}$ & Komunikasi & Penaampilan & Sikap \\
\hline 1 & Staff A & 70 & 70 & 90 & 75 & 80 & 85 & 80 \\
2 & Staff B & 65 & 70 & 80 & 85 & 90 & 85 & 80 \\
3 & Staff C & 68 & 75 & 85 & 80 & 75 & 70 & 90 \\
4 & Staff D & 75 & 80 & 78 & 75 & 70 & 70 & 80 \\
5. & Staff E & 75 & 85 & 75 & 70 & 70 & 75 & 75 \\
\hline
\end{tabular}

7. Menentukan Nilai Kriteria

Pada penelitian ini, penulis menggunakan 7(tujuh) kriteria, yaitu Keahlian, Kedisiplinan, Kepribadian, Kerja

Team, Komunikasi, Penampilan, dan Sikap.

a. Keahlian

Tabel 3. Tabel Kriteria Keahlian

\begin{tabular}{ccc}
\hline Keahlian & Nilai & Bobot \\
\hline Rendah & $20-40$ & \\
Cukup & $41-60$ & $20 \%$ \\
Tinggi & $61-80$ & \\
Sangat Tinggi & $81-100$ & \\
\hline
\end{tabular}

b. Kedisplinan

Tabel 4. Tabel Kriteria Kedisiplinan

\begin{tabular}{ccc}
\hline Keahlian & Nilai & Bobot \\
\hline Rendah & $20-40$ & \\
Cukup & $41-60$ & $10 \%$ \\
Tinggi & $61-80$ & \\
Sangat Tinggi & $81-100$ & \\
\hline
\end{tabular}

c. Kepribadian

Tabel 5. Tabel Kriteria Kepribadian

\begin{tabular}{ccc}
\hline Keahlian & Nilai & Bobot \\
\hline Rendah & $20-40$ & \\
Cukup & $41-60$ & $10 \%$ \\
Tinggi & $61-80$ & \\
Sangat Tinggi & $81-100$ & \\
\hline
\end{tabular}

d. Kerja Team

Tabel 6. Tabel Kriteria Kerja Team

\begin{tabular}{ccc}
\hline Keahlian & Nilai & Bobot \\
\hline Rendah & $20-40$ & \\
Cukup & $41-60$ & $20 \%$ \\
Tinggi & $61-80$ & \\
Sangat Tinggi & $81-100$ & \\
\hline
\end{tabular}

e. Komunikasi

Tabel 7. Tabel Kriteria Komunikasi

\begin{tabular}{ccc}
\hline Keahlian & Nilai & Bobot \\
\hline Rendah & $20-40$ & \\
Cukup & $41-60$ & $20 \%$ \\
Tinggi & $61-80$ & \\
Sangat Tinggi & $81-100$ & \\
\hline
\end{tabular}

f. Penampilan 
JURNAL MEDIA INFORMATIKA BUDIDARMA

Volume 5, Nomor 2, April 2021, Page 495-503

ISSN 2614-5278 (media cetak), ISSN 2548-8368 (media online)

Available Online at https://ejurnal.stmik-budidarma.ac.id/index.php/mib

DOI 10.30865/mib.v5i2.2926

Tabel 8. Tabel Kriteria Penampilan

\begin{tabular}{ccc}
\hline Keahlian & Nilai & Bobot \\
\hline Rendah & $20-40$ & \\
Cukup & $41-60$ & $10 \%$ \\
Tinggi & $61-80$ & \\
Sangat Tinggi & $81-100$ & \\
\hline
\end{tabular}

g. Sikap

Tabel 9. Tabel Kriteria Sikap

\begin{tabular}{ccc}
\hline Keahlian & Nilai & Bobot \\
\hline Rendah & $20-40$ & \\
Cukup & $41-60$ & $10 \%$ \\
Tinggi & $61-80$ & \\
Sangat Tinggi & $81-100$ & \\
\hline
\end{tabular}

8. Nilai Normalisasi

Pada penelitian ini, penulis menggunakan 7 (tujuh) kriteria, yaitu Keahlian, Kedisiplinan, Kepribadian, Kerja Team, Komunikasi, Penampilan, dan Sikap untuk tabel normalisasi dapat dilihat sebagai berikut:

Tabel 10. Tabel Normalisasi

\begin{tabular}{ccc}
\hline Kriteria & Nilai & Bobot \\
\hline Keahlian & $20 \%$ & 0.2 \\
Kedisplinan & $10 \%$ & 0.1 \\
Kepribadian & $10 \%$ & 0.1 \\
Kerja Team & $20 \%$ & 0.2 \\
Komunikasi & $20 \%$ & 0.2 \\
Penampilan & $10 \%$ & 0.1 \\
Sikap & $10 \%$ & 0.1 \\
Jumlah & $100 \%$ & 10 \\
\hline
\end{tabular}

9. Menentukan Nilai Akhir Metode SMARTER:

$$
\text { Rumus: } u\left(a_{1}\right)=\sum_{j_{=1}}^{m} w_{1} u_{1}\left(a_{1}\right)
$$

Pencarian Nilai Akhir Dari Kriteria:

1. Staff $A$

$$
\begin{aligned}
& =(70 * 0.2)+(70 * 0.1)+(90 * 0.1)+(75 * 0.2)+(80 * 0.2)+(85 * 0.1)+(80 * 0.1) \\
& =14+7+9+15+16+8.5+8 \\
& =77.5
\end{aligned}
$$

2. Staff B

$$
=(65 * 0.2)+(70 * 0.1)+(80 * 0.1)+(85 * 0.2)+(90 * 0.2)+(85 * 0.1)+(80 * 0.1)
$$

$=13+7+8+17+18+8.5+8$

$=79.5$

3. Staff C

$$
\begin{aligned}
& =(68 * 0.2)+(75 * 0.1)+(85 * 0.1)+(80 * 0.2)+(75 * 0.2)+(70 * 0.1)+(90 * 0.1) \\
& =13.6+7.5+8.5+16+15+7+9 \\
& =76.6
\end{aligned}
$$

4. Staff D

$=(75 * 0.2)+(80 * 0.1)+(78 * 0.1)+(75 * 0.2)+(70 * 0.2)+(70 * 0.1)+(80 * 0.1)$

$=15+8+7.8+15+14+7+8$

$=74.8$

5. Staff $E$

$=(75 * 0.2)+(85 * 0.1)+(75 * 0.1)+(70 * 0.2)+(70 * 0.2)+(75 * 0.1)+(75 * 0.1)$

$=15+8.5+7.5+14+14+7.5+7.5$

$=74$

Tabel 11. Tabel Hasil Perhitungan

\begin{tabular}{ccc}
\hline Nama Karyawan & Nilai & Peringkat \\
\hline Staff B & 79.5 & 1 \\
Staff A & 77.5 & 2 \\
\hline
\end{tabular}


JURNAL MEDIA INFORMATIKA BUDIDARMA

Volume 5, Nomor 2, April 2021, Page 495-503

ISSN 2614-5278 (media cetak), ISSN 2548-8368 (media online)

Available Online at https://ejurnal.stmik-budidarma.ac.id/index.php/mib

DOI $10.30865 /$ mib.v5i2.2926

\begin{tabular}{ccc}
\hline Nama Karyawan & Nilai & Peringkat \\
\hline Staff C & 76.6 & 3 \\
Staff D & 74.8 & 4 \\
Staff E & 74 & 5 \\
\hline
\end{tabular}

Maka disimpulkan perhitungan diatas nilai rangking tertinggi yaitu Staff B dengan nilai rata-rata 79,5.

\subsection{Penerapan Metode SAW}

Pemilihan staff pegawai berikut perhitungan manual berdasarkan contoh kasus. Diambil 5 sampel calon staff pegawai dengan data sebagai berikut:

1. Sampel Nilai Calon Staff Pegawai

Untuk data rating kecocokan dari alternatif dan kriteria di ambil dari tabel 2 di atas.

2. Matriks Keputusan dari tabel rating

Kecocokan dari setiap alternatif pada setiap kriteria. Pengambilan keputusan memberikan nilai alternatif, berdasarkan tingkat kepentingan masing-masing kriteria yang dibutuhkan sebagai berikut: Vektor bobot $w=[20,10,10,20,20,10,10]$ membuat matriks keputusan $\mathrm{X}$, dibuat dari tabel 2 [12].

$$
X=\left[\begin{array}{ccccccc}
70 & 70 & 90 & 75 & 80 & 85 & 80 \\
65 & 70 & 80 & 85 & 90 & 85 & 80 \\
68 & 75 & 85 & 80 & 75 & 70 & 90 \\
75 & 80 & 78 & 75 & 70 & 70 & 80 \\
75 & 85 & 75 & 70 & 70 & 75 & 75
\end{array}\right]
$$

3. Selanjutnya melakukan normalisasi matriks keputusan $\mathrm{X}$ menjadi matriks ternormalisasi $\mathrm{R}$ dengan cara nilai atribut yang dimiliki dari setiap kriteria Xij dibagi dengan nilai terbesar dari steiap kriteria Max Xij. Dengan cara menghitung niali rating penilaian staff ternormalisasi Rij, berdasarkan persamaan yang disesuaikan dengan jenis kriteria. Untuk semua kriteria ini menggunakan kriteria keuntungan (benefit) [13]

a. Staff A

$$
\begin{aligned}
& R 11=x 11 \frac{x 11}{\max (x 11, x 21, x 31)}=\frac{70}{\max (70,65,68,75,75)}=\frac{70}{75}=0.93 \\
& R 12=x 12 \frac{x 12}{\max (x 12, x 22, x 32)}=\frac{70}{\max (70,70,75,80,85)}=\frac{70}{85}=0.82 \\
& R 13=x 13 \frac{x 13}{\max (x 13, x 23, x 33)}=\frac{90}{\max (90,80,85,78,75)}=\frac{90}{90}=1 \\
& R 14=x 14 \frac{x 14}{\max (x 14, x 24, x 34)}=\frac{75}{\max (75,85,80,75,70)}=\frac{75}{85}=0.88 \\
& R 15=x 15 \frac{x 15}{\max (x 15, x 25, x 35)}=\frac{80}{\max (80,90,75,70,70)}=\frac{80}{90}=0.88 \\
& R 16=x 16 \frac{x 16}{\max (x 16, x 26, x 36)}=\frac{85}{\max (85,85,70,70,75)}=\frac{85}{85}=1 \\
& R 17=x 17 \frac{x 17}{\max (x 17, x 27, x 37)}=\frac{80}{\max (80,80,90,80,75)}=\frac{80}{90}=0.88
\end{aligned}
$$

b. Staff B

$$
\begin{aligned}
& R 11=x 11 \frac{x 11}{\max (x 11, x 21, x 31)}=\frac{65}{\max (70,65,68,75,75)}=\frac{65}{75}=0.86 \\
& R 12=x 12 \frac{x 12}{\max (x 12, x 22, x 32)}=\frac{70}{\max (70,70,75,80,85)}=\frac{70}{85}=0.82 \\
& R 13=x 13 \frac{x 13}{\max (x 13, x 23, x 33)}=\frac{80}{\max (90,80,85,78,75)}=\frac{80}{90}=0.88
\end{aligned}
$$


JURNAL MEDIA INFORMATIKA BUDIDARMA

Volume 5, Nomor 2, April 2021, Page 495-503

ISSN 2614-5278 (media cetak), ISSN 2548-8368 (media online)

Available Online at https://ejurnal.stmik-budidarma.ac.id/index.php/mib

DOI 10.30865/mib.v5i2.2926

$$
\begin{aligned}
& R 14=x 14 \frac{x 14}{\max (x 14, x 24, x 34)}=\frac{85}{\max (75,85,80,75,70)}=\frac{85}{85}=1 \\
& R 15=x 15 \frac{x 15}{\max (x 15, x 25, x 35)}=\frac{90}{\max (80,90,75,70,70)}=\frac{90}{90}=1 \\
& R 16=x 16 \frac{x 16}{\max (x 16, x 26, x 36)}=\frac{85}{\max (85,85,70,70,75)}=\frac{85}{85}=1 \\
& R 17=x 17 \frac{x 17}{\max (x 17, x 27, x 37)}=\frac{80}{\max (80,80,90,80,75)}=\frac{80}{90}=0.88
\end{aligned}
$$

c. Staff C

$$
\begin{aligned}
& R 11=x 11 \frac{x 11}{\max (x 11, x 21, x 31)}=\frac{68}{\max (70,65,68,75,75)}=\frac{68}{75}=0.90 \\
& R 12=x 12 \frac{x 12}{\max (x 12, x 22, x 32)}=\frac{75}{\max (70,70,75,80,85)}=\frac{75}{85}=0.88 \\
& R 13=x 13 \frac{85}{\max (x 13, x 23, x 33)}=\frac{85}{\max (90,80,85,78,75)}=\frac{85}{90}=0.94 \\
& R 14=x 14 \frac{80}{\max (x 14, x 24, x 34)}=\frac{80}{\max (75,85,80,75,70)}=\frac{80}{85}=0.94 \\
& R 15=x 15 \frac{75}{\max (x 15, x 25, x 35)}=\frac{75}{\max (80,90,75,70,70)}=\frac{70}{90}=0.83 \\
& R 16=x 16 \frac{70}{\max (x 16, x 26, x 36)}=\frac{70}{\max (85,85,70,70,75)}=\frac{85}{85}=0.82 \\
& R 17=x 17 \frac{90}{\max (x 17, x 27, x 37)}=\frac{90}{\max (80,80,90,80,75)}=1
\end{aligned}
$$

d. Staff D

$$
\begin{aligned}
& R 11=x 11 \frac{x 11}{\max (x 11, x 21, x 31)}=\frac{75}{\max (70,65,68,75,75)}=\frac{75}{75}=1 \\
& R 12=x 12 \frac{80}{\max (x 12, x 22, x 32)}=\frac{x 12}{\max (70,70,75,80,85)}=\frac{80}{85}=0.94 \\
& R 13=x 13 \frac{78}{\max (x 13, x 23, x 33)}=\frac{78}{\max (90,80,85,78,75)}=\frac{70}{90}=0.86 \\
& R 14=x 14 \frac{x 14}{\max (x 14, x 24, x 34)}=\frac{75}{\max (75,85,80,75,70)}=\frac{75}{85}=0.88 \\
& R 15=x 15 \frac{70}{\max (x 15, x 25, x 35)}=\frac{70}{\max (80,90,75,70,70)}=\frac{70}{90}=0.77 \\
& R 16=x 16 \frac{70}{\max (x 16, x 26, x 36)}=\frac{70}{\max (85,85,70,70,75)}=\frac{85}{80}=0.82 \\
& R 17=x 17 \frac{80}{\max (x 17, x 27, x 37)}=\frac{80}{\max (80,80,90,80,75)}=0.88
\end{aligned}
$$

e. Staff E

$$
R 11=x 11 \frac{x 11}{\max (x 11, x 21, x 31)}=\frac{75}{\max (70,65,68,75,75)}=\frac{75}{75}=1
$$


ISSN 2614-5278 (media cetak), ISSN 2548-8368 (media online)

Available Online at https://ejurnal.stmik-budidarma.ac.id/index.php/mib DOI 10.30865/mib.v5i2.2926

$$
\begin{aligned}
& R 12=x 12 \frac{x 12}{\max (x 12, x 22, x 32)}=\frac{85}{\max (70,70,75,80,85)}=\frac{85}{85}=1 \\
& R 13=x 13 \frac{x 13}{\max (x 13, x 23, x 33)}=\frac{75}{\max (90,80,85,78,75)}=\frac{75}{90}=0.83 \\
& R 14=x 14 \frac{70}{\max (x 14, x 24, x 34)}=\frac{70}{\max (75,85,80,75,70)}=\frac{70}{85}=0.82 \\
& R 15=x 15 \frac{70}{\max (x 15, x 25, x 35)}=\frac{70}{\max (80,90,75,70,70)}=0.77 \\
& R 16=x 16 \frac{70}{\max (x 16, x 26, x 36)}=\frac{75}{\max (85,85,70,70,75)}=\frac{75}{85}=0.88 \\
& R 17=x 17 \frac{x 17}{\max (x 17, x 27, x 37)}=\frac{75}{\max (80,80,90,80,75)}=\frac{75}{90}=0.83
\end{aligned}
$$

4. Matriks ternomalisasi

Hasil dari rating kinerja ternormalisasi akan membentuk matriks ternormalisasi.[14]

$$
R=\left[\begin{array}{ccccccc}
0.93 & 0.82 & 1.00 & 0.88 & 0.88 & 1.00 & 0.88 \\
0.86 & 0.82 & 0.88 & 1.00 & 1.00 & 1.00 & 0.88 \\
0.90 & 0.88 & 0.94 & 0.94 & 0.83 & 0.82 & 1.00 \\
1.00 & 0.94 & 0.86 & 0.88 & 0.77 & 0.82 & 0.88 \\
1.00 & 1.00 & 0.83 & 0.82 & 0.77 & 0.88 & 0.83
\end{array}\right]
$$

5. Nilai Preferensi

Dalam nilai preferensi didapat dari setiap alternatif (Vi) dijumlahkan dengan hasil kasli antara matriks ternormalisasi (R) dengan nilai bobot (W). Nilai preferensi dari setiap alternatif calon staff pegawai terbaik adalah sebagai berikut::[15]

$$
w=[20,10,10,20,20,10,10]
$$

$$
\begin{aligned}
& \text { Staff A }=V 1=(0.93 * 20)+(0.82 * 10)+(1.00 * 10)+(0.88 * 20)+(0.88 * 20)+(1.00 * 10)+(0.88 * 10)=90.8 \\
& \text { Staff B }=V 2=(0.86 * 20)+(0.82 * 10)+(0.88 * 10)+(1.00 * 20)+(1.00 * 20)+(1.00 * 10)+(0.88 * 10)=93 \\
& \text { Staff C }=V 3=(0.90 * 20)+(0.88 * 10)+(0.94 * 10)+(0.94 * 20)+(0.83 * 20)+(0.82 * 10)+(1.00 * 10)=89.8 \\
& \text { Staff D }=V 4=(1.00 * 20)+(0.94 * 10)+(0.86 * 10)+(0.88 * 20)+(0.77 * 20)+(0.82 * 10)+(0.88 * 10)=88 \\
& \text { Staff E }=\text { V5 }=(1.00 * 20)+(1.00 * 10)+(0.83 * 10)+(0.82 * 20)+(0.77 * 20)+(0.88 * 10)+(0.83 * 10)=87.2
\end{aligned}
$$

Tabel 12. Tabel Hasil Perhitungan

\begin{tabular}{ccc}
\hline Nama Karyawan & Nilai & Peringkat \\
\hline Staff B & 93 & 1 \\
Staff A & 90.8 & 2 \\
Staff C & 89.8 & 3 \\
Staff D & 88 & 4 \\
Staff E & 87.2 & 5 \\
\hline
\end{tabular}

Nilai terpilih ada pada V1,V2, dan V3 adalah rekomendasi alternatif yang terpilih sebagai alternatif terbaik. Jika pemilihan 3 staff, satu yang terpilih adalah V2 saja, data disiapkan berdasarkan pada kebutuhan sistem.

\section{KESIMPULAN}

Setelah menyelesaikan penelitian, maka dapat diambil beberapa kesimpulan dan saran sebagai berikut: Metode SMARTER dan SAW adalah metode yang dapat digunakan dalam pengambilan Decision Support System pemilihan staff pegawai laboratorium terbaik. Penentuan rangking pada metode SMARTER dan SAW berdasarkan nilai terbesar sebagai alternatif terbaik. Perangkingan menggunakan metode SMARTER dan SAW pada pemilihan staff pegawai terbaik laboratorium menghasilkan urutan yang sama. Perangkingkan metode SAW lebih teliti dibanding SMARTER karena perhitungan alternatif terbaik didapat pada nilai min Xij dan nilai max Rij.

\section{REFERENCES}

[1] A. P. Windarto, "Penilaian Prestasi Kerja Karyawan PTPN III Pematangsiantar Dengan Metode Simple Additive Weighting (SAW)," Jurasik (Jurnal Ris. Sist. Inf. dan Tek. Inform., vol. 2, no. 1, p. 84, 2017, doi: 


\section{JURNAL MEDIA INFORMATIKA BUDIDARMA}

Volume 5, Nomor 2, April 2021, Page 495-503

ISSN 2614-5278 (media cetak), ISSN 2548-8368 (media online)

Available Online at https://ejurnal.stmik-budidarma.ac.id/index.php/mib

DOI 10.30865/mib.v5i2.2926

10.30645/jurasik.v2i1.22.

[2] R. D. Kusmiyanti and Mustakim, "Analisis Sensitivitas Metode Simple Multi Attribute Rating Technique Terhadap Pembobotan Analytic Hierarchy Process," Semin. Nas. Teknol. Informasi, Komun. dan Ind., no. November, pp. 127-137, 2016.

[3] F. Fahrozi and M. Ula, "UNTUK TANAMAN PANGAN MENGGUNAKAN METODE SMARTER DAN SAW Decision Support System for Appropriate Soil Type for Food Plant using SMARTER and SAW Method,” 2020.

[4] R. Fauzan, Y. Indrasary, and N. Muthia, "Sistem Pendukung Keputusan Penerimaan Beasiswa Bidik Misi di POLIBAN dengan Metode SAW Berbasis Web," J. Online Inform., vol. 2, no. 2, p. 79, 2018, doi: 10.15575/join.v2i2.101.

[5] R. Helilintar, W. W. Winarno, and H. Al Fatta, "Penerapan Metode SAW dan Fuzzy Dalam Sistem Pendukung Keputusan Penerimaan Beasiswa," Creat. Inf. Technol. J., vol. 3, no. 2, p. 89, 2016, doi: 10.24076/citec.2016v3i2.68.

[6] A. S. Putra, D. R. Aryanti, and I. Hartati, "Metode SAW (Simple Additive Weighting) sebagai Sistem Pendukung Keputusan Guru Berprestasi ( Studi Kasus : SMK Global Surya)," Pros. Semin. Nas. Darmajaya, vol. 1, no. 1, pp. 8597, 2018, [Online]. Available: https://jurnal.darmajaya.ac.id/index.php/PSND/article/view/1233/763.

[7] P. Metode, S. A. W. Dan, and M. A. Mude, "Pada Kasus Umkm," vol. 8, no. Agustus, pp. 76-81, 2016.

[8] A. Arga et al., "Implementation of the Topsis Algorithm and Eucs Method for Employee Performance Rating System on the Laboran Fakultas," vol. 7, no. 6, pp. 1137-1146, 2020, doi: 10.25126/jtiik.202072353.

[9] A. Rizkiyanto and I. G. Anugrah, "Implementasi Metode Simple Multy Attribute Rating Technique Exploiting Ranks (Smarter) Dan Forward Chaining Pada Penentuan Posisi Karyawan Baru PT. Langgeng Buana Jaya, Gresik," J. Nas. Komputasi dan Teknol. Inf., vol. 2, no. 2, p. 149, 2019, doi: 10.32672/jnkti.v2i2.1565.

[10] A. Waluyo and N. Fais Irfandi, "Perancangan Sistem Pendukung Keputusan Pemilihan Pegawai Teladan Menggunakan Metode Saw (Simple Additive W eighting) Berbasis Web Di Dinas Penanaman Modal Dan Pelayanan Terpadu Satu Pintu Kabupaten Kebumen,” J. E-Komtek, vol. 3, no. 2, pp. 71-86, 2019, doi: 10.37339/e-komtek.v3i2.132.

[11] N. Silalahi, P. Studi, and T. Informatika, "Bulletin of Information Technology ( BIT ) Sistem Pendukung Keputusan Pemilihan Dosen Berprestasi Menggunakan Metode SMARTER Pada Universitas Budi Darma,” vol. 1, no. 1, pp. 5057, 2020

[12] C. R. Hidayat, T. Mufizar, and M. D. Ramdani, "Implementasi Metode Weighted Product Pada Sistem Pendukung Keputusan Seleksi Calon Karyawan Bpjs Kesehatan Tasikmalaya," Konf. Nas. Sist. Inf. 2018, no. September, pp. 530$541,2018$.

[13] S. Abadi and F. Latifah, "Decision Support System Penilaian Kinerja Karyawan Pada Perusahaan Menggunakan Metode Simple Additive Weighting," J. TAM (Technology Accept. Model., vol. 6, pp. 37-43, 2016.

[14] A. Fitriah and E. Irfiani, "Sistem Pendukung Keputusan Pemilihan Pegawai Terbaik PT Pegadaian Jakarta Dengan Metode Simple Additive Weighting," Inf. Syst. Educ. Prof., vol. 2, no. 2, pp. 105-114, 2018, [Online]. Available: http://ejournal-binainsani.ac.id/index.php/ISBI/article/view/747.

[15] E. G. Wahyuni and A. T. Anggoro, "Sistem Pendukung Keputusan Penerimaan Pegawai dengan Metode TOPSIS," Sains Teknol. dan Ind., vol. 14, no. 2, pp. 108-116, 2017, [Online]. Available: http://ejournal.uinsuska.ac.id/index.php/sitekin/article/view/3907/pdf. 